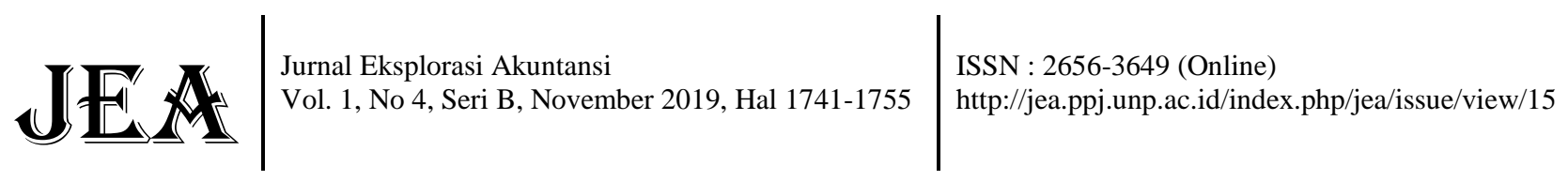

\section{ANALISIS PENGARUH PROFITABILITAS, LIKUIDITAS, KEBIJAKAN DIVIDEN, PERTUMBUHAN PERUSAHAAN DAN STRUKTUR AKTIVA TERHADAP STRUKTUR MODAL}

\author{
Ade Elsa Betavia \\ Jurusan Akuntansi Fakultas Ekonomi, Universitas Negeri Padang \\ *Korespondensi: elsabetavia@gmail.com
}

\begin{abstract}
The purpose of this study was to determine the effect of Profitability (ROE), Liquidity (CR), Dividend Policy (DPR), Growth (Sales Growth), Asset Structure of the Capital Structure (DER). This study population is listed manufacturing industry in Indonesia Stock Exchange in 2010-2014. The method of analysis used in this study is a quantitative method with the statistical analysis of panel data regression. Using Capital Structure as variable dependent and Profitability, Liquidity, Dividend Policy, Growth, Asset Structure as independent variables. Results of the study showed partial Probability (ROE) and Liquidity (CR) significant on the Capital Structure (DER). Dividend Policy (DPR), Growth (sales growth) and Asset Structure not influence significantly to the Capital Structure (DER). Profitability (ROE), Liquidity (CR), Dividend Policy (DPR), Growth (Sales Growth) and Asset Structure simultaneously significant on the Capital Structure (DER).
\end{abstract}

Keywords: Profitability (ROE); Liquidity (CR); Dividend Policy (DPR); Growth (Sales Growth); Asset Structure; Capital Structure (DER)

How to cite (APA $6^{\text {th }}$ style)

Betavia, E., B. (2019). Analisis Pengaruh Profitabilitas, Likuiditas, Kebijakan Deviden, Pertumbuhan Perusahaan dan Struktur Aktiva terhadap Struktur Modal. Jurnal Eksplorasi Akuntansi, 1(4), Seri B, 1741-1755.

\section{PENDAHULUAN}

Perusahaan didirikan dengan tujuan untuk memakmurkan pemilik perusahaan atau pemegang saham. Tujuan ini dapat diwujudkan dengan memaksimumkan nilai perusahaan dengan asumsi bahwa pemilik perusahaan atau pemegang saham akan makmur jika kekayaannya meningkat. Maka dari itu dalam rangka mencapai tujuan tersebut perusahaan seharusnya memperhatikan segala aktivitas perusahaan yang salah satunya adalah pengelolaan keuangan perusahaan. Pengelolaan keuangan itu sendiri dipengaruhi oleh keputusan-keputusan keuangan diantaranya keputusan pendanaan atau pembiayaan.

Keputusan pendanaan adalah keputusan mengenai seberapa besar tingkat penggunaan hutang dibandingkan dengan ekuitas dalam membiayai investasi perusahaan atau keputusan yang bertujuan untuk menentukan struktur modal yang optimal sehingga dapat meningkatkan nilai perusahaan (Sheikh dan Wang, 2011). Kebutuhan akan modal sangatlah penting dalam membangun dan menjamin kelangsungan hidup perusahaan sehingga manajer keuangan harus dengan tepat dan cermat dalam menentukan struktur modalnya. 
Suatu perusahaan dalam permulaan usahanya akan memenuhi kebutuhan dananya dengan mengutamakan pemenuhan sumber dari internal perusahaan, sehingga dapat mengurangi ketergantungan kepada pihak luar. Sesaat setelah usaha yang dijalankan ini berkembang, perusahaan dituntut untuk mencari alternatif pendanaan dari sumber yang lain, dan dalam hal ini dari luar perusahaan (sumber eksternal). Perusahaan dalam menggunakan sumber eksternal akan terlebih dahulu memilih menggunakan hutang, baik itu jangka pendek, ataupun jangka panjang sebelum menerbitkan saham. Hal ini sesuai dengan pecking order theory yang dikemukakan oleh Myers dan Majluf (1984). Pecking order theory (POT) menyatakan bahwa "penentuan sumber modal yang optimal didasarkan pada keputusan pendanaan secara hierarki berdasarkan biaya modal yang paling murah yang bersumber pada sumber dana internal (profit) sampai pada sumber dana eksternal (hutang dan saham).

Struktur modal merupakan masalah yang penting bagi perusahaan karena baik buruknya struktur modal akan mempunyai efek langsung terhadap posisi finansial perusahaan, yang pada akhirnya akan mempengaruhi nilai perusahaan. Struktur modal menunjukkan proporsi atas penggunaan hutang untuk membiayai investasinya, sehingga dengan mengetahui struktur modal, investor dapat mengetahui keseimbangan antara risiko dan tingkat pengembalian investasinya. Kesalahan dalam menentukan struktur modal akan berdampak luas terutama apabila perusahaan terlalu besar dalam menggunakan hutang, sehingga beban tetap yang harus ditanggung perusahaan semakin besar pula. Hal ini juga berarti akan meningkatkan risiko finansial, yaitu risiko saat perusahaan tidak dapat membayar beban bunga atau angsuran-angsuran hutangnya. Struktur modal juga dinyatakan sebagai proporsi pendanaan dengan hutang (debt financing) perusahaan, yaitu rasio leverage (pengungkit) perusahaan. Dengan demikian, hutang adalah unsur dari struktur modal perusahaan. Struktur modal merupakan kunci perbaikan produktivitas dan kinerja perusahaan.

Karena keputusan mengenai struktur modal ini sangat penting dalam perusahaan maka sebaiknya manajer dalam suatu perusahaan perlu memperhatikan faktor-faktor dalam penentuan struktur modal sehingga jika keputusan itu tepat akan bisa memaksimalkan nilai perusahaan. Untuk penelitian ini terdapat faktor-faktor yang akan dijadikan objek penelitian yang berhubungan dengan struktur modal yaitu profitabilitas, likuiditas, kebijakan dividen, pertumbuhan perusahaan dan stuktur aktiva. Penelitian mengenai struktur modal bertujuan untuk menentukan model atau teori struktur modal yang dapat menjelaskan perilaku keputusan pendanaan perusahaan dan pada akhirnya akan bermuara pada tinggi rendahnya nilai perusahaan. Meskipun secara teori, faktor-faktor yang mempengaruhi keputusan struktur modal sulit diukur, namun berbagai penelitian empiris yang bertujuan untuk mengidentifikasi faktor-faktor yang mempengaruhi keputusan pendanaan perusahaan telah banyak dilakukan.

Penelitian-penelitian terdahulu yang dilakukan memiliki hasil yang berbeda-beda diantaranya penelitian yang dilakukan Ogbulu and Emeni (2012) dalam penelitiannya menyimpulan tangibility, growth dan profitability tidak memiliki dampak yang signifikan terhadap struktur modal. Berbeda hasilnya dengan penelitian Sari dan Haryanto (2013) menyatakan bahwa profitabilitas, likuiditas, dan pertumbuhan aset berpengaruh negatif terhadap struktur modal. Begitu juga penelitian yang dilakukan oleh Wijaya dan Utama (2014) yang menyatakan bahwa profitabilitas berpengaruh terhadap stuktur modal dan harga saham sedangkan pertumbuhan penjualan tidak berpengaruh terhadap struktur modal dan harga saham. Berbeda dengan penelitian yang dilakukan Saleem et all (2013) menunjukkan sebaliknya bahwa pertumbuhan perusahaan berpengaruh negatif terhadap struktur modal. 
Hasil penelitian Seftianne dan Handayani (2011) menunjukkan bahwa struktur asset tidak berpengaruh terhadap struktur modal, sedangkan pada penelitian Wijaya dan Utama (2014) struktur aset berpengaruh terhadap struktur modal. Penelitian yang berhubungan dengan kebijakan dividen memiliki hasil yang juga kontradiktif diataranya Mulyono (2009) hasil penelitian menunjukkan bahwa struktur modal berpengaruh positif signifikan terhadap kebijakan dividen.

Dalam penelitian ini, peneliti mengambil populasi yaitu seluruh perusahaan manufaktur yang terdaftar di BEI dalam kurun waktu 2010-2014. Alasan pemilihan populasi ini karena perusahaan manufaktur merupakan perusahaan dengan skala produksi yang besar atau mempunyai volume perdagangan yang besar dan membutuhkan modal atau dana yang besar pula untuk mengembangkan produknya serta melakukan ekspansi pasar sehingga akan mempengaruhi keputusan struktur modal atau pendanaan suatu perusahaan. Selain itu pemilihan perusahaan manufaktur sebagai objek penelitian dikarenakan perusahaan manufaktur memiliki kepekaan terhadap perubahan ekonomi baik jangka panjang maupun jangka pendek.

Berdasarkan penjelasan di atas dan perbedaan hasil penelitian terdahulu yang berbeda beda maka penulis tertarik melakukan penelitian dengan judul "Analisis Pengaruh Profitabilitas, Likuiditas, Kebijakan Dividen, Pertumbuhan Perusahaan dan Struktur Aktiva terhadap Struktur Modal".

\section{REVIU LITERATUR DAN HIPOTESIS \\ Teori Modigliani-Miller (MM) Tanpa Pajak}

Teori struktur modal modern yang pertama adalah teori Modigliani dan Miller (teori MM). Mereka berpendapat bahwa struktur modal tidak relevan atau tidak mempengaruhi nilai perusahaan. MM mengajukan beberapa asumsi untuk membangun teori mereka Brigham dan Houston (2006:33) yaitu tidak terdapat agency cost, tidak ada pajak, investor dapat berutang dengan tingkat suku bunga yang sama dengan perusahaan, investor mempunyai informasi yang sama seperti manajemen mengenai prospek perusahaan di masa depan, tidak ada biaya kebangkrutan, Earning Before Interest and Taxes (EBIT) tidak dipengaruhi oleh penggunaan dari utang.

\section{Teori Modigliani-Miller (MM) Dengan Pajak}

Teori MM tanpa pajak dianggap tidak realistis dan kemudian MM memasukkan faktor pajak kedalam teorinya. Pajak dibayarkan kepada pemerintah, yang berarti merupakan aliran kas keluar. Utang bisa digunakan untuk menghemat pajak, karena bunga bisa dipakai sebagai pengurang pajak. Implikasi teori tersebut adalah perusahaan sebaiknya menggunakan utang sebanyak-banyaknya. Dalam prakteknya, tidak ada perusahaan yang mempunyai utang sebesar itu, karena semakin tinggi tingkat utang suatu perusahaan, akan semakin tinggi juga kemungkinan kebangkrutannya. Inilah yang melatar belakangi teori MM mengatakan agar perusahaan menggunakan utang sebanyak-banyaknya, karena MM mengabaikan biaya kebangkrutan

\section{Trade-off Theory}

Menurut trade-off theory yang diungkapkan oleh Myers (2001) mengungkapkan bahwa perusahaan akan berhutang sampai pada tingkat utang tertentu, dimana penghematan pajak (tax shields) dari tambahan hutang sama dengan biaya kesulitan keuangan (financial distress)". Biaya kesulitan keuangan (financial distress) adalah biaya kebangkrutan (bankruptcy costs) atau 
reorganization, dan biaya keagenan (agency costs) yang meningkat akibat dari turunnya kredibilitas suatu perusahaan. Trade-off theory dalam menentukan struktur modal yang optimal memasukkan beberapa faktor antara lain pajak, biaya keagenan (agency costs) dan biaya kesulitan keuangan (financial distress) tetapi tetap mempertahankan asumsi efisiensi pasar dan symmetric information sebagai imbangan dan manfaat penggunaan utang.

\section{Pecking Order Theory}

Teori lain dari struktur modal yaitu pecking order theory yang dikemukakan oleh Myers dan Maljuf pada tahun 1984. Teori ini secara ringkas menjelaskan mengenai keputusan pendanaan yang menyatakan bahwa perusahaan cenderung menggunakan sumber pendanaan internal (retained earnings) terlebih dahulu yaitu dari laba yang ditahan dan depresiasi, daripada menggunakan dana eksternal (hutang, saham) dari aktivitas pendanaan. Pecking order theory tidak mengindikasikan target struktur modal. Pecking order theory menjelaskan urut-urutan pendanaan.

\section{Struktur Modal}

Ada beberapa pengertian atau definisi dari struktur modal oleh beberapa ahli yang menuangkannya dalam buku mereka, diantaranya adalah Menurut Sawir (2005:10), struktur modal adalah pendanaan permanen yang terdiri dari utang jangka panjang, saham preferen, dan modal pemegang saham. Struktur modal adalah perimbangan atau perbandingan antara jumlah hutang jangka panjang dengan modal sendiri. Apabila dihubungkan dengan pengertian pembelanjaan kuantitatif dan pembelanjaan kualitatif maka dapat dikatakan bahwa kebijakan dalam pembelanjaan kuantitatif akan menentukan kapitalisasi dan kebijakan dalam pembelanjaan kualitatif akan menentukan struktur modal suatu perusahaan (Riyanto, 2001: 282).

Brigham dan Houston (2006:6), struktur modal yang ditargetkan adalah bauran atau perpaduan dari utang, saham preferen, saham biasa yang dikehendaki perusahaan dalam struktur modalnya. Struktur modal yang optimal adalah gabungan ekuitas yang memaksimumkan harga saham perusahaan. Jadi dapat disimpulkan struktur modal adalah hasil atau akibat dari keputusan pendanaan (financing decision) yang intinya memilih apakah menggunakan utang atau ekuitas untuk mendanai operasi perusahaan. Menurut Brigham dan Houston (2006:7) ada empat faktor yang mempengaruhi keputusan struktur modal, yaitu risiko bisnis, posisi pajak perusahaan, fleksibilitas keuangan, konservatisme atau agresivitas manajemen

\section{Profitabilitas}

Profitabilitas (profitability) adalah kemampuan perusahaan memperoleh laba melalui operasional usahanya dengan menggunakan dana aset yang dimiliki oleh perusahaan. Profitabilitas merupakan kemampuan perusahaan didalam menghasilkan laba. Profitabilitas mencerminkan keuntungan dari investasi keuangan. Myers dan Majluf (1984) berpendapat bahwa manajer keuangan yang menggunakan pecking order theory dengan laba ditahan sebagai pilihan pertama dalam pemenuhan kebutuhan dana dan hutang sebagai pilihan kedua serta penerbitan saham sebagai pilihan ketiga, akan selalu memperbesar profitabilitas untuk meningkatkan laba.

Profitabilitas sebagai tolak ukur dalam menentukan alternatif pembiayaan, namun cara untuk menilai profitabilitas suatu perusahaan adalah bermacam-macam dan sangat tergantung pada laba dan aktiva atau modal yang akan dibandingkan dari laba yang berasal dari operasi perusahaan atau laba netto sesudah pajak dengan modal sendiri. Dengan adanya berbagai cara dalam penelitian profitabilitas suatu perusahaan tidak mengherankan bila ada beberapa 
perusahaan yang mempunyai perbedaan dalam menentukan suatu alternatif untuk menghitung profitabilitas. Hal ini bukan keharusan tetapi yang paling penting adalah profitabilitas mana yang akan digunakan, tujuannya adalah semata-mata sebagai alat mengukur efisiensi penggunaan modal di dalam perusahaan yang bersangkutan. Menurut Kasmir (2008:196) Rasio profitabilitas merupakan rasio untuk menilai kemampuan perusahaan dalam mencari keuntungan. Rasio ini juga memberikan ukuran tingkat efektifitas manajemen suatu perusahaan. Hal ini ditunjukkan oleh laba yang dihasilkan dari penjualan dan pendapatan investasi. Pada dasarnya penggunaan rasio ini yakni menunjukkan tingkat efesiensi suatu perusahaan.

Secara umum ada empat jenis analisis utama yang digunakan untuk menilai tingkat profitabilitas yakni terdiri dari Net Profit Margin (NPM), Gross Profit Margin (GPM), Return On Assets (ROA). Return On Equity (ROE)

\section{Likuiditas}

Menurut Wild (2005: 185) likuiditas merupakan kemampuan untuk mengubah aktiva menjadi kas atau kemampuan untuk memperoleh kas. Menurut Munawir (2002:31) likuiditas adalah menunjukkan kemampuan suatu perusahaan untuk memenuhi kewajiban keuangannya yang harus segera dipenuhi, atau kemampuan perusahaan untuk memenuhi kewajiban keuangan pada saat ditagih. Secara umum pengertian likuiditas (liquidity) mengacu pada kemampuan perusahaan untuk memenuhi kewajiban jangka pendeknya.

Likuiditas Riyanto (2001: 67) adalah berhubungan dengan masalah kemampuan suatu perusahaan untuk memenuhi kewajiban finansialnya yang segera harus dipenuhi. Untuk menilai likuiditas perusahaan terdapat beberapa rasio yang dapat digunakan sebagai alat untuk menganalisa dan menilai posisi likuiditas perusahaan, yaitu current ratio, diperoleh dari aktiva lancar dibagi dengan hutang lancar, dan acid ratio, diperoleh dari aktiva lancar dikurangi persediaan dibagi dengan hutang lancar.

\section{Kebijakan Dividen}

Dividen merupakan return yang diterima oleh pemegang saham karena telah menanamkan dananya pada perusahaan Suhadak dan Darmawan (2011:62). Kebijakan dividen menyangkut keputusan- keputusan apakah laba akan dibayarkan sebagai laba atau ditahan untuk reinvestasi dalam perusahaan Sawir (2004:137). Menurut Riyanto (2001:281) kebijakan dividen bersangkutan dengan penentuan pembagian pendapatan (earning) antara penggunaan pendapatan untuk dibayarkan kepada pemegang saham sebagai dividen atau untuk digunakan di dalam perusahaan, yang berarti pendapatan tersebut harus ditahan di dalam perusahaan.

\section{Pertumbuhan Perusahaan}

Pertumbuhan perusahaan (growth) pada dasarnya mencerminkan produktivitas perusahaan dan merupakan suatu harapan yang diinginkan oleh pihak internal (manajemen) maupun pihak eksternal (investor dan kreditor) perusahaan. Pertumbuhan (Growth) merupakan indikator maju tidaknya suatu perusahaan. Suatu perusahaan dapat dikatakan mengalami pertumbuhan ke arah yang lebih baik jika terdapat peningkatan yang konsisten dalam aktivitas utama operasinya. Suatu perusahaan dengan pertumbuhan positif (meningkat) adalah indikator majunya perusahaan tersebut.

Growth dapat diukur dengan menggunakan indikator pertumbuhan aktiva (assets growth) dan pertumbuhan penjualan (sales growth). Pertumbuhan aktiva (assets growth) menggambarkan kenaikan atau penurunan aktiva setiap tahun, sedangkan pertumbuhan penjualan (sales growth) 
menggambarkan kenaikan atau penurunan penjualan setiap tahun. Bagi perusahaan dengan tingkat pertumbuhan penjualan dan laba yang tinggi kecenderungan menggunakan utang sebagai sumber dana eksternal lebih besar dibandingkan dengan perusahaan-perusahaan yang tingkat pertumbuhan penjualannya rendah. Perusahaan dengan pertumbuhan yang stabil dapat lebih aman sehingga memungkinkan dapat lebih banyak pinjaman, dan menanggung beban tetap yang lebih tinggi dibandingkan dengan perusahaan yang penjualannya tidak stabil.

\section{Struktur Aset}

Aset adalah segala sumber daya dan harta yang dimiliki perusahaan untuk digunakan dalam operasinya. Suatu perusahaan pada umumnya memiliki dua jenis aktiva yaitu aktiva lancar dan aktiva tetap. Kedua unsur aktiva ini akan membentuk struktur aktiva. Struktur aktiva suatu perusahaan akan tampak dalam sisi sebelah kiri neraca. Struktur aktiva juga disebut struktur asset atau struktur kekayaan. Struktur aktiva menggambarkan sebagian jumlah aktiva yang dapat dijadikan jaminan (collateral value of assets). Secara umum, perusahaan yang memiliki jaminan terhadap hutang akan lebih mudah mendapatkan hutang dari pada perusahaan yang tidak memiliki jaminan terhadap hutang. Pada umumnya, perusahaan yang memiliki proporsi struktur aktiva yang lebih besar kemungkinan juga akan lebih mapan dalam industri, memiliki risiko lebih kecil, dan akan menghasilkan tingkat leverage yang besar.

\section{Pengembangan Hipotesis}

$\mathrm{H}_{1}$ : Profitabilitas berpengaruh signifikan terhadap struktur modal

$\mathrm{H}_{2}$ : Likuiditas berpengaruh signifikan terhadap struktur modal

$\mathrm{H}_{3}$ : Kebijakan dividen berpengaruh signifikan terhadap struktur modal

$\mathrm{H}_{4}$ : Pertumbuhan perusahaan berpengaruh signifikan terhadap struktur modal

$\mathrm{H}_{5}$ : Struktur aktiva berpengaruh signifikan terhadap struktur modal

\section{METODE PENELITIAN Jenis Penelitian}

Penelitian ini merupakan penelitian empiris yang dilakukan dengan cara menganalisis data secara historis, menggunakan analisis regresi untuk menguji adanya pengaruh yang signifikan antara profitabilitas, likuiditas, kebijakan deviden, pertumbuhan perusahaan dan struktur aktiva terhadap struktur modal pada perusahaan manufaktur yang terdaftar di Bursa Efek Indonesia tahun 2010-2014. Penelitian ini tergolong sebagai penelitian kuantitatif karena data penelitian berupa angka-angka dan analisis menggunakan statistik.

\section{Populasi dan Sampel}

Populasi merupakan wilayah generelisasi yang terdiri atas objek/subjek yang mempunyai kualitas dan karakteristik tertentu yang ditetapkan oleh peneliti untuk dipelajari dan ditarik kesimpulannya. Populasi dalam penelitian ini merupakan perusahaan-perusahaan manufaktur yang terdaftar di Bursa Efek Indonesia mulai tahun 2010-2014 sebanyak 141 perusahaan. Penelitian ini menggunakan teknik purposive sampling, yang merupakan teknik penentuan sampel dengan pertimbangan tertentu atau teknik pengambilan sampel dari kelompok target spesifik. 
Tabel 1

Proses Seleksi Sampel Berdasarkan Kriteria

\begin{tabular}{|l|l|l|}
\hline No. & Kriteria Sampel Penelitian & Total Emiten \\
\hline 1. & $\begin{array}{l}\text { Total Perusahaan manufaktur yang terdaftar di Bursa Efek Indonesia } \\
\text { (BEI) selama tahun 2010-2014 }\end{array}$ & 141 \\
\hline 2. & $\begin{array}{l}\text { Dikurangi perusahaan manufaktur yang tidak terdaftar secara berturut- } \\
\text { turut di Bursa Efek Indonesia (BEI) dan delist (keluar) dari BEI } \\
\text { selama periode penelitian yaitu dari tahun 2010- 2014 }\end{array}$ & 22 \\
\hline 3. & $\begin{array}{l}\text { Dikurangi perusahaan yang tidak menyajikan laporan keuangan } \\
\text { tahunan yang telah diaudit per 31 Desember untuk tahun 2010-2014 } \\
\text { serta tidak memiliki data yang dibutuhkan dengan lengkap dalam } \\
\text { penelitian ini. }\end{array}$ & 39 \\
\hline 4. & Dikurangi laporan keuangan yang tidak menggunakan satuan rupiah. & 20 \\
\hline & $\begin{array}{l}\text { Jumlah sampel penelitian yang memenuhi kriteria. } \\
\text { Jadi total observasi penelitian yang memenuhi kriteria selama 5 5 } \\
\text { tahun pengamatan }\end{array}$ & $\mathbf{3 0 0}$ \\
\hline
\end{tabular}

\section{Jenis dan Sumber Data}

Data yang digunakan dalam penelitian ini adalah data sekunder. Data sekunder dalam penelitian ini adalah laporan keuangan (annual report) perusahaan-perusahaan manufaktur yang terdaftar di Bursa Efek Indonesia selama periode 2010-2014.

\section{Teknik Pengumpulan Data}

Pada penelitian ini, pengumpulan data dilakukan dengan teknik dokumentasi yang dilakukan dengan mengumpulkan data-data tentang perusahaan yang menjadi sampel penelitian melalui fasilitas internet dengan mengunakan situs-situs resmi perusahaan serta informasi dari media lainya.

\section{Variabel Penelitian dan Definisi Operasional}

Variabel dalam penelitian ini terbagi menjadi variabel eksogen atau variabel bebas yaitu profitabilitas (profitability), likuiditas (liquidity), kebijakan deviden (dividend policy), pertumbuhan perusahaan (growth), dan struktur aktiva (asset structure) serta variabel endogen atau variabel terikat yaitu struktur modal (capital stucture) dan nilai perusahaan (firm value).

Tabel 2

\section{Definisi Operasional Variabel}

\begin{tabular}{|l|l|l|c|}
\hline Jenis Variabel & \multicolumn{1}{|c|}{ Nama variabel } & \multicolumn{1}{|c|}{ Devinisi Operasional } & $\begin{array}{c}\text { Skala } \\
\text { Pengukuran }\end{array}$ \\
\hline Independent & $\begin{array}{l}\text { Profitabilitas : } \\
\text { Return On Equity }\left(\mathrm{X}_{1}\right)\end{array}$ & $\begin{array}{l}\text { Kemampuan perusahaan untuk } \\
\text { memperoleh laba yang tersedia bagi } \\
\text { pemegang saham. }\end{array}$ & Rasio \\
& $\begin{array}{l}\text { Likuiditas : } \\
\text { Current Ratio }\left(\mathrm{X}_{2}\right)\end{array}$ & $\begin{array}{l}\text { Kemampuan perusahaan dalam } \\
\text { membayar kewajiban jangka pendeknya } \\
\text { dengan menggunakan aktiva lancar } \\
\text { yang dimiliki. }\end{array}$ & Rasio \\
\hline & $\begin{array}{l}\text { Kebijakan Deviden: } \\
\text { Dividend Payout Ratio } \\
\left.\mathrm{X}_{3}\right)\end{array}$ & $\begin{array}{l}\text { Kebijakan menyangkut keputusan- } \\
\text { keputusan apakah laba akan dibayarkan } \\
\text { sebagai laba atau ditahan untuk } \\
\text { reinvestasi dalam perusahaan }\end{array}$ & Rasio \\
\hline & $\begin{array}{l}\text { Pertumbuhan Perusahaan } \\
\text { Sales growth }\left(\mathrm{X}_{4}\right)\end{array}$ & $\begin{array}{l}\text { Cerminan produktivitas perusahaan dan } \\
\text { merupakan suatu harapan yang }\end{array}$ & Rasio \\
\hline
\end{tabular}




\begin{tabular}{|l|l|l|c|}
\hline & & $\begin{array}{l}\text { diinginkan oleh pihak internal maupun } \\
\text { pihak eksternal perusahaan. }\end{array}$ & \\
\hline & Stuktur aktiva $\left(\mathrm{X}_{5}\right)$ & $\begin{array}{l}\text { Perbandingan antara aktiva tetap dan } \\
\text { total aktiva yang dapat menentukan } \\
\text { besarnya alokasi dana untuk masing- } \\
\text { masing komponen aktiva. }\end{array}$ & Rasio \\
\hline Dependent & $\begin{array}{l}\text { Struktur Modal: } \\
\text { Debt to Equity Ratio }\left(Y_{1}\right)\end{array}$ & $\begin{array}{l}\text { Pendanaan permanen yang terdiri dari } \\
\text { utang jangka panjang, saham preferen, } \\
\text { dan modal pemegang saham. }\end{array}$ & Rasio \\
\hline
\end{tabular}

\section{Teknik Analisis Data}

\section{Analisis Statistik Deskriptif}

Statistik deskripsi memberikan informasi mengenai data yang akan diuji dalam penelitian dan memberikan gambaran mengenai sesuatu data yang dilihat dari mean, standar deviasi, minimal, maksimal, tabel dan lain-lain.

\section{Pemilihan Model Regresi Panel}

Widarjono (2007:231) mengemukakan bahwa terdapat tiga metode yang digunakan untuk mengestimasi model regresi data panel yaitu :

1. Koefisien tetap Antar Waktu dan Individu (common effect atau pooles least squere)..

2. Slope Konstan Tetapi Intersep Berbeda Antar Individu (fixed effect).

3. Estimasi Dengan Pendekatan Random Effects.

Dua teknik estimasi model regresi data panel di atas dapat dipilih satu yang paling tepat untuk mengestimasi regresi data panel. Tiga uji yang digunakan, pertama uji Chow atau $F$ Restricted digunakan untuk memilih antara metode common effect atau fixed effect. Kedua, uji Hausman untuk memilih antara fixed effect atau random effect yang terbaik dalam mengestimasi regresi data panel. Dan yang terakhir LM test yang digunakan untuk memilih antara PLS dan RE.

\section{Uji Asumsi Klasik}

Dengan pengujian ini diharapkan agar model regresi data panel yang diperoleh bisa dipertanggung jawabkan dan tidak bias maka asumsi-asumsi dasar yang harus dipenuhi uji multikolinearitas, uji heteroskedastisitas, uji autokorelasi.

\section{d. Uji Hipotesis}

Uji hipotesis dilakukan dengan Uji Determinan, Uji t dan Uji F

\section{PEMBAHASAN DAN HASIL PENELITIAN \\ Analisis Statistik Deskriptif}

Statistik deskriptif memberikan gambaran dari nilai rata-rata (mean), standar deviasi, nilai minimum, nilai maksimum dan lain sebagainya. 
Tabel. 3

Statistik Deskriptif

\begin{tabular}{|l|l|l|l|l|l|}
\hline & $\mathrm{N}$ & Maksimum & Minimum & Mean & Standar Deviasi \\
\hline ROE & 300 & 1,63 & $-1,53$ & 0,153 & 0,317 \\
\hline CR & 300 & 11,74 & 0,11 & 2,175 & 1,776 \\
\hline DPR & 300 & 1 & 0 & 0,208 & 0,264 \\
\hline SG & 300 & $-0,57$ & 5,91 & 0,164 & 0,419 \\
\hline SA & 300 & 0,001 & 0,82 & 0,341 & 0,194 \\
\hline DER & 300 & $-10,34$ & 22,46 & 1,354 & 2,315 \\
\hline
\end{tabular}

Sumber data : Hasil Olah Data STATA 12

\section{Pemilihan Regresi Data Panel}

Pemilihan model tergantung pada asumsi yang dipakai oleh peneliti dan pemenuhan syaratsyarat pengolahan data statistik yang benar, sehingga hasilnya dapat dipertanggungjawabkan secara statistik. Oleh karena itu, langkah pertama yang harus dilakukan adalah memilih model yang tepat dari ketiga model yang tersedia. Data panel yang telah dikumpulkan, diregresikan dengan menggunakan model pooled least square, yang hasilnya dapat dilihat pada dan tabel 4 . Sedangkan untuk hasil regresi dengan model fixed effect dapat dilihat pada dan tabel 5

Pada tabel 4 dan 5 didapatkan hasil dari model pool least square dan fixed effect diperoleh maka selanjutnya dilakukan $F$ Restricted atau Chow Test. Pengujian tersebut dibutuhkan untuk memilih model yang paling tepat diantara model pool least square dan fixed effect. Dalam uji ini yang akan dilihat adalah nilai prob $\mathrm{F}$ dimana jika nilai tersebut kecil dari alfa maka Ho akan ditolak dimana dalam test ini H0 : PLS dan H1 : FE. Dari tabel diatas terlihat bahwa prob $\mathrm{F}$ sebesar 0,0000 dan kecil dari nilai alpa yang 0,05 sehingga dari $F$ Restricted diputuskan bahwa $\mathrm{H} 0$ ditolak sehingga model yang digunakan adalah model fixed effect.

\section{Tabel 4}

Hasil regresi stuktur modal dengan ROE, CR, DPR, SG dan SA dengan mengunakan Pooled Least Square (PLS)

Namber of obs $=300$

$\mathrm{F}(5,294)=18,65$

Prob $>\mathrm{F}=0,00$

R-squared $=0,24$

\begin{tabular}{|l|r|r|r|r|r|r|}
\hline DER & \multicolumn{1}{|l|}{ Coef } & \multicolumn{1}{l|}{ Std.Err } & \multicolumn{1}{l|}{ T } & \multicolumn{1}{|c|}{ P> $|\mathbf{t}|$} & \multicolumn{2}{|c|}{ (95\% Coef. Internal) } \\
\hline ROE & $-3,113$ & 0,406 & $-7,67$ & 0,000 & $-3,192$ & $-2,314$ \\
CR & $-0,334$ & 0,702 & $-4,74$ & 0,000 & $-0,473$ & $-0,196$ \\
DPR & 0,532 & 0,492 & 1,08 & 0,281 & $-0,437$ & 1,502 \\
SG & 0,607 & 0,282 & 2,15 & 0,033 & 0,050 & 1,163 \\
SA & $-1,453$ & 0,63 & $-2,31$ & 0,022 & $-2,693$ & $-0,212$ \\
Cons & 2,846 & 0,335 & 8,47 & 0,000 & 2,185 & 3,508 \\
\hline
\end{tabular}

Sumber data : Hasil Olah Data STATA 1 


\section{Tabel 5}

Hasil regresi stuktur modal dengan ROE, CR, DPR, SG dan SA dengan mengunakan Fixed Effect (FE)

$\begin{array}{rlr}\mathrm{R}-\mathrm{sq}: \text { within }=0,3945 & \text { Number of obs } & =300 \\ \text { between }=0,0120 & \mathrm{~F}(5,235) & =30,63 \\ \text { overall }=0,0932 & \text { Prob }>\mathrm{F} & =0,0000\end{array}$

\begin{tabular}{|c|c|c|c|c|c|c|}
\hline DER & Coef & Std.Err & $\mathbf{T}$ & $P>|t|$ & \multicolumn{2}{|c|}{ (95\% Coef. Internal) } \\
\hline ROE & $-3,683$ & 0,406 & $-7,67$ & 0,000 & $-3,192$ & $-2,314$ \\
\hline $\mathrm{CR}$ & $-0,098$ & 0,702 & $-4,74$ & 0,000 & $-0,473$ & $-0,196$ \\
\hline DPR & $-1,34$ & 0,492 & 1,08 & 0,281 & $-0,437$ & 1,502 \\
\hline SG & 0,685 & 0,282 & 2,15 & 0,033 & 0,050 & 1,163 \\
\hline SA & $-9,037$ & 0,63 & $-2,31$ & 0,022 & $-2,693$ & $-0,212$ \\
\hline Cons & 5,388 & 0,335 & 8,47 & 0,000 & 2,185 & 3,508 \\
\hline sigma_u & 2,269 & & & & & \\
\hline sigma_e & 1,539 & & & & & \\
\hline Rho & 0,684 & (fraction of & variance $d u$ & to $\left.u \_i\right)$ & & \\
\hline
\end{tabular}

$F$ test that all $u_{-} i=0: \quad \mathrm{F}(59,235)=4,72 \quad$ Prob $>\mathrm{F}=0,0000$

Sumber data : Hasil Olah Data STATA 12

Selanjutnya akan dilakukan regresi dengan model random effect untuk menentukan model regresi panel yang tepat. Hasil dari regresi dengan menggunakan model random effect dapat dilihat pada dan tabel 6

\section{Tabel 6}

Hasil regresi stuktur modal dengan ROE, CR, DPR, SG dan SA dengan mengunakan Random Effect (RE)

$\begin{array}{rlr}\text { R-sq : within }=0,3462 & \text { Number of obs } & =300 \\ \text { between }=0,1076 & \text { Wald chi } 2(5) & =120,51 \\ \text { overall }=0,2132 & \text { Prob }>\text { chi } 2 & =0,0000\end{array}$

\begin{tabular}{|l|r|r|r|r|r|r|}
\hline \multicolumn{1}{|c|}{ DER } & \multicolumn{1}{c|}{ Coef } & \multicolumn{1}{c|}{ Std.Err } & \multicolumn{1}{c|}{$\mathbf{z}$} & \multicolumn{1}{c|}{$\mathbf{P}>|\mathbf{z}|$} & \multicolumn{2}{c|}{$(\mathbf{9 5 \%}$ Coef. Internal $)$} \\
\hline ROE & $-3,523$ & 0,373 & $-9,43$ & 0,000 & $-4,254$ & $-2,791$ \\
CR & $-0,224$ & 0,862 & $-2,60$ & 0,000 & $-0,393$ & 0,055 \\
DPR & $-0,307$ & 0,554 & $-0,55$ & 0,580 & -1.394 & 0,779 \\
SG & 0,728 & 0,241 & 3,02 & 0,002 & 0,256 & 1,201 \\
SA & $-2,905$ & 0,899 & $-3,23$ & 0,001 & $-4,669$ & $-1,141$ \\
Cons & 3,320 & 0,454 & 7,31 & 0,000 & 2,429 & 4,210 \\
\hline sigma_u & 1,210 & \multicolumn{7}{|l}{} \\
sigma_e & 1,539 & \\
Rho & 0,381 & (fraction of variance due to $\left.u \_i\right)$ & \\
\hline
\end{tabular}

Sumber data : Hasil Olah Data STATA 12

Mengingat belum dapat ditentukan model mana yang akan kita gunakan. Oleh karena itu diperlukan uji Hausman untuk mengetahuinya. Pada tabel 7 disajikan hasil dari uji Hausman yang telah dilakukan dengan menggunakan Stata 12. Dalam Hausman Test H0 : RE sedangkan FE adalah $\mathrm{H} 1$ dengan kriteria jika nilai $\mathrm{P}$ value (Prob>Chi2) < alpha 0,05 maka H1 diterima atau 
yang berarti pilihan terbaik adalah FE dari pada RE. Hasil uji Hausman dapat dilihat pada tabel dibawah ini :

Tabel 7

Hasil Hausman test fe re regresi Struktur Modal

\begin{tabular}{|c|c|c|c|c|}
\hline & $\begin{array}{l}\text { (b) } \\
\mathrm{Fe}\end{array}$ & $\begin{array}{l}\text { (B) } \\
\operatorname{Re}\end{array}$ & $\begin{array}{r}\boldsymbol{b} \text {-BChi } 2 \\
\text { Difference } \\
\end{array}$ & 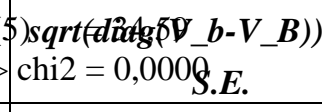 \\
\hline ROE & $-3,683$ & $-3,523$ & $-0,16$ & 0,134 \\
\hline $\mathrm{CR}$ & $-0,098$ & $-0,244$ & 0,125 & 0,071 \\
\hline DPR & $-1,34$ & $-0,307$ & $-1,032$ & 0,432 \\
\hline SG & 0,685 & 0,728 & $-0,432$ & . \\
\hline SA & $-9,03777$ & $-2,905$ & $-6,132$ & 1,443 \\
\hline
\end{tabular}

Sumber data : Hasil Olah Data STATA 12

Dari tabel diatas terlihat bahwa Prob>chi2 sebesar 0,0000 dimana kecil dari alpa 0,05 sehingga diputuskan bahwa H0 ditolak dan H1 diterima. Dengan hasil ini jelaslah bahwa model yang digunakan untuk data panel adalah Fixed Effect (FE).

\section{Uji Asumsi Klasik}

Setelah menentukan model regresi panel data yang akan digunakan, maka langkah selanjutnya adalah menguji dan memenuhi asumsi yang diperlukan untuk pengujian suatu data panel. Pengujian yang diperlukan adalah uji multikolinieritas, heteroskedastisitas, dan autokorelasi

\section{a. Uji Multikolinieritas}

Asumsi pertama yang kita uji adalah tidak adanya multikolinearitas. Multikolinearitas adalah adanya hubungan antar variabel independen. Untuk mendetekesi multikolinearitas kita lihat dengan melihat tolerance value (1/VIF) dan variance inflation factor (VIF). Dalam penelitian ini memiliki dua model regresi pertama model regresi untuk melihat pengaruh ROE, CR, DPR, SG dan SA terhadap stuktur modal (DER). Hasil multikolinieritasnya dapat dilihat pada tabel 8 di bawah ini :

Tabel 8

Hasil Uji Multikolinieritas

\begin{tabular}{|l|r|r|}
\hline \multicolumn{1}{|c|}{ Variabel } & \multicolumn{1}{c|}{ VIF } & \multicolumn{1}{c|}{$\mathbf{1 / \text { VIF }}$} \\
\hline ROE & 1,45 & 0,698 \\
CR & 1,77 & 0,563 \\
DPR & 1,96 & 0,509 \\
SG & 1,11 & 0,903 \\
SA & 1,73 & 0,578 \\
\hline
\end{tabular}

Hasil analisis menunjukkan bahwa nilai VIF semua variabel independen dibawah nilai 10 dan nilai tolerance (1/VIF) diatas 0,10 . Dari hasil menunjukkan bahwa tidak ada multikolineritas antar variabel independen dalam model regresi. 


\section{b. Uji Heteroskedastisitas}

Asumsi kedua adalah tidak adanya Heterokedastisitas. Heterokedastisitas adalah adanya varian dari variabel gangguan (residual) yang tidak konstan. Uji heterokedasitas untuk panel data yang bisa dipakai adalah Wald Test. Berikut hasil Wald test for heteroskedasticity in panel data:

Tabel 9

Hasil uji heteroskedasitas

$\begin{gathered}\text { chi2 }(60)=1.5 \mathrm{e}+06 \\ \text { Prob }>\text { chi } 2=0,0000\end{gathered}$
Sumber data: Hasil Olah Data STATA 12

Berikut hipotesis uji Wald test for heteroskedasticity in panel data :

H0 : Tidak terdapat heteroscedasticity

$\mathrm{H} 1$ : Terdapat heteroscedasticity

Berdasarkan hasil pengujian dengan Stata 12, ternyata probabilitas dari uji Wald test panel data lebih kecil dari 0.05 yang mengindikasikan tolak $\mathrm{H} 0$ atau model terpilih masih terdapat masalah heteroscedasticity.

\section{c. Uji Autokorelasi}

Uji autokorelasi untuk panel data yang biasa dipakai adalah wooldridgetest. Berikut hasil wooldridgetest for autocorrelation in panel data. Hasil dari uji ini dapat dilihat dari tabel di bawah ini :

Tabel 10

\section{Hasil uji autokorelasi}

$$
\begin{aligned}
& F(1,59)=6,338 \\
& \text { Prob }>F=0,0146
\end{aligned}
$$

Sumber data : Hasil Olah Data STATA 12

Wooldridge test mendeteksi autocorrelation berdasarkan hasil pengujian dengan Stata 12, ternyata probabilitas dari uji data lebih kecil dari 0.05 yang mengindikasikan tolak $\mathrm{H} 0$ dan terima $\mathrm{H} 1$ atau model terpilih terdapat autocorrelation. Begitu juga dengan persamaan yang ke dua juga terdapat masalah autokorelasi karena terlihat nilai Prob < alfa (0.05).

Berdasarkan hasil uji heteroskedastisitas dan uji autokorelasi, model yang digunakan memiliki masalah heteroskedastisitas dan autokorelasi. Oleh karena itu, agar model menjadi blue, terlebih dahulu harus dilakukan modifikasi model. Pada stata, kita dapat melakukan modifikasi lainnya yakni dengan menggunakan pendekatan Panel-Corrected Standard Errors, dimana metode ini akan mengatasi masalah heteroskedasticity dan autokorelasi. Untuk pengaruh ROE, CR DPR, SG dan SA terhadap DER dengan model regresi FE model berikut sudah bisa mengatasi masalah heteroskedastisitas dan autokorelasi. Berikut outputnya pada tabel 11 . 
Tabel 11

Hasil Estimasi dengan Pendekatan Panel-Corrected Standard Errors

$$
\begin{array}{ll}
\text { Namber of obs }= & 300 \\
R-\text { squared } & =0,2228 \\
\text { Prob }>\text { chi } 2 & =0,0001
\end{array}
$$

\begin{tabular}{|l|c|r|r|r|lr|}
\hline \multirow{2}{*}{ DER } & \multicolumn{6}{|c|}{ Panel-corrected } \\
\cline { 2 - 7 } & Coef & \multicolumn{1}{c|}{ Std.Err } & \multicolumn{1}{c|}{$\mathbf{Z}$} & \multicolumn{1}{c|}{$\mathbf{P}>|\mathbf{z}|$} & \multicolumn{1}{|c|}{ (95\% Coef. Internal) } \\
\hline ROE & $-2,722$ & 0,925 & $-2,94$ & 0,003 & $-4,536$ & $-0,908$ \\
CR & $-0,220$ & 0,734 & $-3,00$ & 0,003 & $-0,364$ & $-0,763$ \\
DPR & $-0,662$ & 0,544 & $-1,22$ & 0,223 & $-1,729$ & 0,403 \\
SG & 0,546 & 0,552 & 0,99 & 0,323 & $-0,536$ & 1,629 \\
SA & $-2,661$ & 1,768 & $-1,50$ & 0,132 & $-6,128$ & 0,805 \\
Cons & 3,176 & 0,633 & 5,01 & 0,000 & 1,934 & 4,417 \\
\hline Rho & 0,646 & \multicolumn{5}{|c}{} \\
\hline
\end{tabular}

Sumber data : Hasil Olah Data STATA 12

\section{Uji Hipotesis}

\section{Uji Koefisien Determinasi (Adjusted $\boldsymbol{R}^{2}$ )}

Hasil koefisien determinasi dapat dilihat dalam tabel 11. Dari tabel tersebut diperoleh angka $R$ Square $\left(\square^{2}\right.$ ) dari tahun 2010 sampai 2014 adalah sebesar 0,2228 atau 22,28\%. Hal ini menunjukkan bahwa variabel independen ( ROE, CR, DPR, SG dan SA) dapat menjelaskan variabel dependen (struktur modal / DER) sebesar 22,28\%. Sedangkan sisanya dipengaruhi oleh variabel lain yang tidak dimasukkan dalam model penelitian ini.

\section{b. Uji t (Parsial)}

Hasil uji t dapat dilhat pada

Tabel. 12.

Uji T

\begin{tabular}{|l|c|l|l|l|l|}
\hline Variabel & Coef & $\mathrm{P}>|\mathrm{z}|$ & \multicolumn{1}{|c|}{ Hasil } & \multicolumn{2}{|c|}{ Keterangan } \\
\hline ROE & $-2,722$ & 0,003 & H0 ditolak & $\begin{array}{l}\text { Profitabilitas berpengaruh signifikan terhadap } \\
\text { struktur modal }\end{array}$ \\
\hline CR & $-0,220$ & 0,003 & H0 ditolak & $\begin{array}{l}\text { Likuiditas berpengaruh signifikan terhadap struktur } \\
\text { modal }\end{array}$ \\
\hline DPR & $-0,662$ & 0,223 & H0 diterima & $\begin{array}{l}\text { Kebijakan dividen tidak berpengaruh signifikan } \\
\text { terhadap struktur modal }\end{array}$ \\
\hline SG & 0,546 & 0,323 & H0 diterima & $\begin{array}{l}\text { Pertumbuhan perusahaan tidak berpengaruh } \\
\text { signifikan terhadap struktur modal }\end{array}$ \\
\hline SA & $-2,661$ & 0,132 & H0 diterima & $\begin{array}{l}\text { Struktur aktiva tidak berpengaruh signifikan } \\
\text { terhadap struktur modal }\end{array}$ \\
\hline
\end{tabular}

\section{Uji F (Simultan)}

\section{Pengujian Hipotesis}

Terlihat pada tabel 11 didapatkan bahwa nilai probabilitas sebesar 0,0001 yang mana lebih kecil dari nilai signifikan sebesar 0,05. Dengan demikian maka H0 ditolak sehingga Ha diterima. 
Dapat dinyatakan bahwa secara simultan profitabilitas, likuiditas, kebijakan dividen, pertumbuhan perusahaan dan struktur aktiva berpengaruh signifikan terhadap struktur modal.

\section{KESIMPULAN, KETERBATASAN DAN SARAN Kesimpulan}

Penelitian ini bertujuan untuk menyajikan bukti empiris mengenai pengaruh profitabilitas (ROE), likuiditas (CR), kebijakan dividen (DPR), pertumbuhan perusahaan (SG), stuktur aktiva (SA) terhadap struktur modal (D) pada perusahaan manufaktur yang terdaftar di Bursa Efek Indonesia (BEI) tahun 2010-2014. Kesimpulan hasil analisis data dapat dilihat sebagai berikut :

1. Dari hasil uji koefisien determinasi $\left(\square^{2}\right)$ didapatkan bahwa variabel independen ( ROE, CR, DPR, SG dan SA) dapat menjelaskan variabel dependen (struktur modal / DER) sebesar 22,28 $\%$.

2. Secara parsial dapat disimpulkan bahwa profitabilitas (ROE) dan likuiditas (CR) berpengaruh signifikan terhadap struktur modal (DER). Sedangkan variabel kebijakan dividen (DPR), pertumbuhan perusahaan (SG) dan struktur aktiva (SA) tidak berpengaruh secara signifikan terhadap struktur modal (DER).

3. Secara simultan dengan uji $F$ yang dilakukan didapatkan bahwa secara bersama-sama profitabilitas (ROE), likuiditas (CR), kebijakan dividen (DPR), pertumbuhan perusahaan (SG) dan stuktur aktiva (SA) berpengaruh signifikan terhadap struktur modal (DER) pada perusahaan manufaktur yang terdaftar di Bursa Efek Indonesia (BEI) tahun 2010-2014.

\section{Keterbatasan Penelitian}

Penulis menyadari masih terdapat kekurangan dalam penelitian ini. Adapun keterbatasan tersebut diantaranya :

1. Sampel penelitian yang digunakan dalam penelitian ini hanya terbatas pada perusahaan manufaktur yang terdaftar di Bursa Efek Indonesia (BEI) tahun 2010-2014, sehingga generalisasi ini hanya terbatas pada perusahaan yang ada, hal ini membuat generalisasi hasil temuan dan rekomendasi penelitian ini kurang dapat dilakukan untuk objek penelitian di luar perusahaan yang diteliti.

2. Variabel dalam penelitian hanya terbatas pada profitabilitas (ROE), likuiditas (CR), kebijakan dividen (DPR), pertumbuhan perusahaan (SG), stuktur aktiva (SA), struktur modal (DER), apabila dalam penelitian selanjutnya ada penambahan variabel kemungkinan akan membuat variasi hasil pengamatan yang saling melengkapi.

\section{Saran}

Penulis memberikan beberapa implikasi dari penelitian ini untuk penelitian mendatang, yaitu :

1. Menggunakan sampel yang lebih besar dengan mengambil sampel yang lebih besar dan dapat meneliti sampel untuk sektor perusahaan yang berbeda

2. Peneliti selanjutnya mungkin dapat mempertimbangkan untuk menambah variabel- variabel penelitian yang mempengaruhi struktur modal dan nilai perusahaan. 


\section{DAFTAR PUSTAKA}

Brigham, F. H dan Houston J. F, (2006). Dasar-dasar manajemen Keuangan terjemahan Ali Akbar Yuliato, Buku satu, Edisi sepuluh, Salemba Empat, Jakarta

Kasmir. (2008). Analisis Laporan Keuangan. Jakarta: PT.Raja Grafindo Persada.

Munawir S. (2002). Analisis Laporan Keuangan, Edisi Kedua, YPKN, Yogyakarta.

Myers, S. C., and Majluf N.S. (1984). Corporate Financing and Investment Decisions When Firmz Have Information That Investors Do Not Have. Journal of Financial Economics, (13), 187-221

Myers, S. C. 2001. Capital Structure. Journal of Economic Perspective. Spring, 15 (2), 81-102.

Mulyono, B, 2009. Pengaruh Debt To Equity Ratio, Insider Ownership, Size, Dan Investment Opportunity Set Terhadap Kebijakan Dividen (Studi Pada Industri Manufaktur yang Terdaftar Di Bursa Efek Indonesia Periode Tahun 2005-2007), Tesis, Universitas Dipenogoro, Semarang.

Riyanto, B. (2001). Dasar-Dasar Pembelanjaan Perusahaan. Edisi 4: Yogyakarta.

Sari, D. V dan Haryanto M.A. (2013). Pengaruh Profitabilitas, Pertumbuhan Aset, Ukuran Perusahaan, Struktur Aktiva dan Likuiditas terhadap Struktur Modal. Diponegoro Journal Bisnis and Management. 2 (3), 1.

Saleem, F., Bisma R, Qaiser M., at all. (2013). The Determinants of Capital Structure of Oil and Gas Firms Listed on Karachi stock Exchange In Pakistan. Interdisciplinary Journal of Contemporary Research In Business, 4 (9), 225-235

Sawir, A, (2005). Analisis Kinerja Keuangan dan Perencanaan Keuangan Perusahaan. Cetakan kelima, PT Gramedia Pustaka Utama, Jakarta.

Seftianne dan Handayani R. (2011). Analisis Faktor-Faktor yang Mempengaruhi Struktur Modal Pada Perusahaan Publik Sektor manufaktur. Jurnal Bisnis dan Akuntansi. 13(1), 39-56.

Sheikh, N. A and Wang Z, (2011). Determinants of Capital Structure An Empirical Study of Firms in Manufacturing Industry of Pakistan, Journal Managerial Finance, 37, 117-133

Suhadak, dan Darmawan A. (2011). Pemikiran Kebijakan Manajemen Keuangan. Malang: CV. Okani Bukaka Malang

Widarjono, A. (2007). Ekonometrika Teori dan Aplikasi. Yogyakarta : Ekonisia FE UII

Wijaya, I. P. A.S dan Utama, I M.K. (2014). Pengaruh Profitabilitas, Struktur Aset dan Pertumbuhan Penjualan Terhadap Struktur Modal Serta Harga Saham. E-Jurnal Akuntansi Universitas Udayana 6(3), 514-530

Wild, John J, Subramanyam, dan Robert F.H, (2005). Analisis Laporan Keuangan terjemahan Yanivis Bachtiar dan S.Nurwahyu Harahap, Edisi Kedelapan, Jilid 1, Penerbit Salemba Empat, Jakarta.

www.idx.co.id 